\section{Effect of extractive content on fuelwood characteristics of certain woody and non-woody biomass}

\author{
Ritesh Kumar*, N. Chandrashekar, \\ N. R. R. Prasad and Ritesh Tailor \\ Institute of Wood Science and Technology, 18th Cross Malleswaram, \\ Bengaluru 560 003, India
}

In this study, the effect of extractive content on fuel properties of selected woody and non-woody biomass samples has been evaluated. The results show significant variation in the amount of extractives (15-70\%) present in different biomass samples. There is significant decrease in ash content, fixed carbon content and calorific value in extractive-free samples. The elemental carbon reduces after extraction in woody biomass. There is no specific trend observed in the reduction of elemental carbon with removal of extractives in nonwoody samples. In extractive-free samples, ash content decreases by $2-60 \%$, fixed carbon content by $7-24 \%$ and calorific value by $1-17 \%$. In conclusion, fuel properties of unextracted biomass are found to be better than extracted biomass.

Keywords: Biomass, calorific value, extractives, fuelwood.

THE environmental concerns associated with fossil fuels has necessitated the demand of heat and energy from renewable sources. Biomass is one of the potential renewable energy sources. It is a cost-effective, environment-friendly and locally available fuel. Biomass energy accounts for almost $9 \%$ of the total primary energy supply of the world ${ }^{1}$. In 2016 , around $2 \%$ of the world's total electricity $(500 \mathrm{TWh})$ was generated using biomass ${ }^{1}$. The demand for electricity and transport fuel from biomass is increasing worldwide as policies today are mainly focused on low-carbon energy system. Compared to other fuels, biomass has advantages of high reactivity and less ash content ${ }^{2}$. It can be easily converted into high-energycontent fuel through thermochemical and biochemical energy conversion processes. The choice of the energyconversion process mainly depends upon chemical properties of biomass and the desired form of energy output ${ }^{3}$.

Plant materials are chemically composed of three polymers: cellulose $(35-50 \%)$, hemicellulose $(20-35 \%)$ and lignin $(10-25 \%)^{4}$. Chemical constituents other than lignin and carbohydrate are extraneous components, such as extractives and other inorganic residues ${ }^{4,5}$. Although extraneous materials are not part of the structural cellwall polymer, they help characterize each species physically and chemically ${ }^{5}$. Energy present in biomass is a function of its chemical composition. The heating value

\footnotetext{
*For correspondence. (e-mail: ritesh@icfre.org)
}

of biomass is greatly influenced by its elemental composition: lignin content, quantity of ash and extractive content $^{6-8}$. In the present study, we have examined the variability in fuel properties of a range of woody and non-woody biomass samples. These feedstock are generally used for briquetting and direct combustion in India. Energy value of biomass depends upon its biochemical composition and is influenced by extractives. In this study, we have evaluated the influence of extractive content on fuelwood characteristics of selected biomass samples.

Sample collection was based on the distribution and quantity of biomass residue resource in Karnataka, India. All test samples were obtained from their main cropproduction areas. Samples of coffee husk and arecanut husk were obtained from Chikkamagaluru district; groundnut shell and cotton stalk from Dharwad district and Lantana camara, rice husk and bagasse from Bengaluru. A minimum of four trees of Prosopis juliflora were sampled (45-55 cm girth) and harvested for analysis. These trees were obtained from Ballari district of Karnataka. A disc of about $10 \mathrm{~cm}$ thickness was cut from breast height position $(\approx 1.3 \mathrm{~m}$ above the ground) for experiments $^{8}$. These disc samples were debarked and dried before chipping and powdering. All experimental samples were oven-dried to constant weight at $80^{\circ} \mathrm{C}$, and then pulverized to fine powder using a Wiley mill.

The diverse nature and composition of extractives in biomass require both polar and non-polar solvents for total extraction ${ }^{4}$. A combination of ethanol and toluene is used to extract oils, fats, waxes and resins, whereas hot water is required to remove pectins, mucilages, gums, tannins, starch, etc. The method described by Senelwa and $\mathrm{Sims}^{7}$ was slightly modified and used for the determination of extractive content. Sample which passed through $250 \mu \mathrm{m}$ mesh sieve but were retained on $180 \mu \mathrm{m}$ mesh sieve were used for the determination of extractive content. A known quantity of oven-dried and powdered biomass sample was weighed into a thimble. The thimbles were kept in Soxhlet apparatus and extraction was carried out using acetone : ethanol: toluene, $(1: 1: 4 \mathrm{v} / \mathrm{v})$ for $10-12 \mathrm{~h}$. These samples were extracted for another $6 \mathrm{~h}$ using ethanol (95\%). After extraction, thimbles were dried to constant weight for determination of organic solvent extractives (OSEs). The samples were further boiled in distilled water (polar solvent) at $100^{\circ} \mathrm{C}$ for 3-4 h. After hot-water extraction, the samples were again oven-dried to constant weight at $80^{\circ} \mathrm{C}$. The sum of polar and non-polar solvent extractives is termed as total extractive content (TEC). The extractive-free sample was used for further analysis. One gram of wood powder was pelleted, oven-dried to constant weight at $80^{\circ} \mathrm{C}$, and burned in an oxygen bomb calorimeter (LECO AC-350, USA) to determine calorific value. The ash content, volatile matter content (on dry basis) and fixed carbon content were determined according to ASTM D5142 using 


\section{RESEARCH COMMUNICATIONS}

Table 1. Chemical composition of different woody and non-woody biomass

\begin{tabular}{lcccc}
\hline Biomass feedstock & $\begin{array}{c}\text { Lignin content } \\
(\% \text { oven dry wt) }\end{array}$ & $\begin{array}{c}\text { Holo-cellulose content } \\
\text { (\% oven dry wt) }\end{array}$ & $\begin{array}{c}\text { OEC } \\
(\% \text { oven dry wt) }\end{array}$ & $\begin{array}{c}\text { TEC } \\
(\% \text { oven dry wt) }\end{array}$ \\
\hline Arecanut husk & ND & ND & $41( \pm 3.2)$ & 70.3 \\
Bagasse & 27 & 60 & $3.1( \pm 0.7)$ & 23.7 \\
Coffee husk & 30 & 56 & $12.1( \pm 1.4)$ & 34.5 \\
Cotton stalk & 20 & 65 & $3.8( \pm 0.7)$ & 14.6 \\
Groundnut shell & 28 & 69 & $2.3( \pm 0.6)$ & 22.6 \\
Rice husk & 15 & 47 & $12.3( \pm 0.5)$ & 14.7 \\
Prosopis juliflora & 30 & 65 & $3.5( \pm 0.8)$ & 17.7 \\
Lantana camara & 25 & 65 & 18.1 \\
\hline
\end{tabular}

ND, Not determined; OEC, Organic solvent soluble extractives; TEC, Total extractive content.

proximate analyzer (LECO TGA-701, USA). The elemental parameters (carbon and hydrogen) were determined using a CHN analyzer (LECO-CHN-2000, USA). The lignin content of biomass was determined by digesting extractive-free samples with $72 \%$ sulphuric acid for $2 \mathrm{~h}$ (ref. 9). The holocellulose content was determined using a standard method ${ }^{10}$. Data analysis was performed using SYSTAT13 and SPSS statistical software. One-way analysis of variance was performed to understand statistically significant differences in calorific value of different biomass samples (extracted and unextracted). All pairwise multiple comparisons were performed using Tukey test. Biomass feedstocks with the same superscript character are not statistically significant at 5\% level of significance.

Extractives in biomass are non-structural aromatic compounds such as alkaloids, proteins, phenolics, simple sugars, pectins, mucilages, gums, fats, oils, waxes, resins, and terpenes. They function as intermediates in tree metabolism, as energy reserves and defence tools against microbial attack. Extractives impart colour, odour and durability to wood. The amount of extractive in biomass varies from species to species. Extractives and lignin have relatively lower degree of oxidation and considerably higher heat of combustion than cellulose and hemicellulose ${ }^{6}$. High heating value of holocellulose is around $18.6 \mathrm{MJ} / \mathrm{kg}$, whereas for lignin it is around $23-25 \mathrm{MJ} / \mathrm{kg}$ (ref. 11). The important parameters that affect the quality of fuel are its chemical composition, extractives and ashforming minerals ${ }^{6,8}$. Table 1 summarizes the results on chemical composition and amount of extractive content present in selected biomass samples. TEC varied between $14 \%$ and $70 \%$ in non-woody biomass and it was $18 \%$ in woody samples. The highest extractive content (70\%) was recorded in arecanut samples. The lignin percentage varied from 15 to 30 in non-woody biomass. Highest lignin content $(30 \%)$ was found in coffee husk samples. The amount of lignin in woody biomass varied between $25 \%$ and $30 \%$ (Table 1 ).

The influence of TEC on fuel properties has been studied; Table 2 summarizes the results. The properties of unextracted and extracted samples were found to be significantly different. Calorific value of extractive-free samples was found significantly lower than unextracted samples. Calorific value decreased by almost $1-17 \%$ in extractive-free sample. Except coffee husk and rice husk, calorific value was significantly higher in all unextracted samples. High calorific value in extracted coffee husk sample may be attributed to reduction in its ash content by almost $10 \%$ (Tables 1 and 2 ). In general, the results indicate positive contribution of extractive content towards increasing calorific value in biomass. Similar observations were made by other researchers in different species ${ }^{6,8}$. Variability in calorific value was found more in non-woody biomass (14.7-21.3 MJ/kg) than woody biomass $(18.7-21.3 \mathrm{MJ} / \mathrm{kg})$. The same can be attributed to complex biochemical composition of non-woody biomass compared to woody biomass, which is primarily composed of cellulose, hemicellulose and lignin.

Ash content is an important parameter which influences calorific value ${ }^{12}$. Higher amount of ash in biomass reduces its heating value ${ }^{9}$. The results presented in Table 2 confirm the contribution of extractives towards ashforming minerals in biomass. A significant reduction in ash content (10-60\%) was observed in all extractive-free samples, except for groundnut shells (Table 2). Although the amount of ash content decreased significantly in extracted samples, calorific value of unextracted samples remained higher (Table 2). This indicates a greater and positive contribution of extractive content towards increasing calorific value compared to adverse influence of ash content.

The fixed carbon content is another important parameter for comparing fuel properties of different feedstocks. High fixed carbon content corresponds to high energy value of fuel ${ }^{12}$. As shown in Table 2, unextracted samples have more fixed carbon content than extracted samples. Except in coffee husk and groundnut shells, a significant reduction in fixed carbon content was observed in all extracted samples (Table 2). Depending upon the type of biomass, almost $7-24 \%$ of extractives chemically transform into fixed carbon content during thermal decomposition process (Table 2). During combustion, when the biomass is heated, the volatiles escape first and burn in 


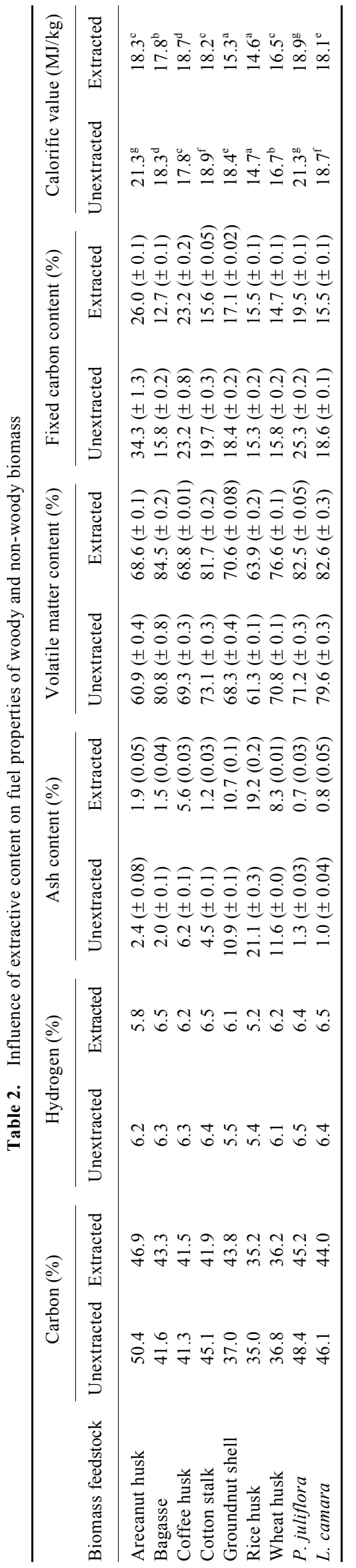


gaseous state leaving behind the fixed carbon as char, which burns later in solid state. Since the heat of combustion of carbon is higher than that of volatile matter, a high proportion of fixed carbon content in unextracted samples has expectedly increased their calorific value (Table 2). Table 2 clearly demonstrates an increase in volatile matter content following extraction. The decomposition of cellulose at $260^{\circ}-350^{\circ} \mathrm{C}$ is mainly responsible for production of flammable volatiles. Except in coffee husk, a significant increase in volatile matter content is observed in all extracted samples (Table 2). Anatomically, extractives permeate both the cell wall and cell lumen ${ }^{5}$. They offer sufficient resistance to easy escape of volatiles from the biomass. The higher volatile matter content in extractive free samples may be due to easy escape of volatiles due to clear internal pathways ${ }^{5}$.

In any fuel, carbon-oxygen and carbon-hydrogen bonds contain lower energy than carbon-carbon bonds. Higher proportion of oxygen and hydrogen in biomass reduces the energy value of fuel ${ }^{13}$. Elemental analysis results clearly show that there is large variation in elemental composition among woody and non-woody biomass samples (Table 2). Variability in the amount of elemental carbon was more in non-woody biomass (35-50\%) than woody biomass (46-48\%). The extractive-free woody biomass samples were found to have significantly less elemental carbon. Elemental carbon of extracted woody samples reduced by $4.5-6.6 \%$. Lack of any particular trend in reducing elemental carbon following removal of extractives from non-woody samples can be attributed to complex biochemical composition of non-woody biomass. TEC in arecanut sample was found to be around $70 \%$; however, only $7 \%$ reduction in elemental carbon was observed in extractive-free biomass. This shows that not all extractives contribute towards elemental carbon or fixed carbon content in the biomass.

The fuel properties of woody and non-woody biomass samples have been analysed. The variability in fuel properties is found to be higher in non-woody biomass compared to woody biomass. The result shows that fuel properties of biomass are greatly influenced by extractive content. Extractive content in biomass contributes towards higher calorific value, ash content and fixed carbon content. The extractive-free biomass has higher volatile matter content. The elemental carbon in woody biomass reduces after extraction, but no particular trend is seen in non-woody biomass.

1. IEA, Technology roadmap-delivering sustainable bioenergy. International Energy Agency, 2017; https://webstore.iea.org/ technology-roadmap-delivering-sustainable-bioenergy

2. Mckendry, P., Energy production from biomass (part 1): overview of biomass. Bioresour. Technol., 2002, 83(1), 37-46.

3. Mckendry, P., Energy production from biomass (part 2): conversion technologies. Bioresour. Technol., 2002, 83, 47-54.

4. Sjostrom, E., Wood Chemistry, Fundamentals and Applications, Academic Press, New York, USA, 2003, 2nd edn.
5. Walker, J. C. F., Primary Wood Processing - Principles and Practice, Springer, The Netherlands, 2006, chapter 13.

6. White, R. H., Effect of lignin content and extractives on higher heating value of wood. Wood Fiber Sci., 1987, 19(4), 446-452.

7. Senelwa, K. and Sims, R. E. H., Fuel characteristics of short rotation forest biomass. Biomass Bioenergy, 1999, 17, 127-140.

8. Moya, R. and Tenorio, C., Fuelwood characteristics and its relation with extractives and chemical properties of ten fast-growing species in Costa Rica. Biomass Bioenergy, 2013, 56, 14-21.

9. Bodirlau, R., Teaca, C. A. and Spiridon, I., Chemical modification of beech wood: effect on thermal stability. BioResources, 2008, 3, 789-800.

10. Technical Association of the Pulp and Paper Industry (1954). Holocellulose in Wood. Official Standard T19M-54, New York, TAPPI.

11. Demirbas, A., Relationships between lignin contents and heating values of biomass. Energy Convers. Manage., 2001, 42, 183-188.

12. Kataki, R. and Konwrer, D., Fuelwood characteristics of some indigenous woody species of northeast India. Biomass Bioenergy, 2001, 20, 17-23.

13. Kumar, R., Pandey, K. K., Chandrashekar, N. and Mohan, S., Study of age and height wise variability on calorific value and other fuel properties of Eucalyptus hybrid, Acacia auriculaeformis and Casuarina equisetifolia. Biomass Bioenergy, 2011, 35, 13391344.

ACKNOWLEDGEMENT. We thank the Karnataka Forest Department for providing experimental material for this work.

Received 25 September 2019; revised accepted 21 November 2019

doi: $10.18520 / \mathrm{cs} / \mathrm{v} 118 / \mathrm{i} 6 / 966-969$

\section{Smart automatic irrigation controller}

\author{
Faruk Poyen $^{1, *}$, Sayan Hazra ${ }^{1}$, \\ Nabarun Sengupta ${ }^{1}$, Apurba Ghosh ${ }^{1}$ and \\ Palash Kundu ${ }^{2}$
}

${ }^{1}$ University Institute of Technology, Golapbag (North), Burdwan 713 104, India

${ }^{2}$ Electrical Engineering, Jadavpur University, Kolkata 700 032, India

\begin{abstract}
Adherence to outdated irrigation techniques causes massive water wastage. In this article, a device is prototyped to curtail this wastage of water by optimizing the irrigation requirements. The design, named smart automatic irrigation controller (SAIC) measures the necessary parameters and determines evapotranspiration (ET) loss. The fuzzy rule based design, evaluates the process variables and generates an output regulation to compensate for the water loss due to ET. The model has two units, viz. wireless sensor unit (WSU) and wireless information processing unit (WIPU) to perform the stated operations. The device is connected
\end{abstract}

*For correspondence. (e-mail: faruk.poyen@gmail.com) 